\title{
Oxidative stability during frozen storage of fillets from silver catfish (Rhamdia quelen) sedated with the essential oil of Aloysia triphylla during transport
}

\author{
Estabilidade oxidativa de filés congelados de jundiás (Rhamdia quelen) sedados \\ com o óleo essencial de Aloysia triphylla durante o transporte
}

\author{
Ana Paula Daniel ${ }^{\text {II }}$ Lauren Fresinghelli Ferreira ${ }^{\text {II }}$ Bruna Klein ${ }^{\text {II }}$ Amanda Roggia Ruviaro ${ }^{\text {II }}$ \\ Andréia Quatrin ${ }^{\mathrm{II}}$ Thaylise Vey Parodi ${ }^{\mathrm{II}}$ Carla Cristina Zeppenfeld ${ }^{\mathrm{III}}$ Berta Maria Heinzmann $^{\mathrm{IV}}$ \\ Bernardo Baldisserotto ${ }^{\mathrm{III}}$ Tatiana Emanuelli ${ }^{\mathrm{II}^{*}}$
}

\section{ABSTRACT}

This research aimed to evaluate whether the essential oil of Aloysia triphylla (EOAT) used in vivo as a sedative in the water for transporting fish could increase the oxidative stability of silver catfish (Rhamdia quelen) fillets during frozen storage. The chemical composition of EOAT and of fillets from fish exposed to $\operatorname{EOAT}\left(0,30\right.$ or $\left.40 \mu L L^{-1}\right)$ were assessed. The $p H$ and lipid oxidation parameters (conjugated dienes, $C D$; thiobarbituric acid-reactivesubstances, TBARS) were evaluated in the fillets throughout the storage period $\left(-18 \pm 2^{\circ} \mathrm{C} / 17\right.$ months). The main compounds found in EOAT were $\alpha$ - and $\beta$-citral. Treatment with EOAT did not modify the proximate composition of the fillets, but $40 \mu L L^{-1}$ EOAT reduced $p H$ levels when compared to the control fillets $(P<0.05)$. Compared to the control fillets, the fillets from fish treated with 30 and $40 \mu \mathrm{L}$ $L^{-1} E O A T$ had higher initial $C D$ values $(P<0.05)$, whereas fillets from fish treated with $40 \mu \mathrm{L} L^{-1} E O A T$ had lower TBARS levels after 6, 9 and 17 months of storage $(P<0.05)$. Results indicated that use of EOAT as a sedative in silver catfish transport water delays the degradation of primary oxidation products $(C D)$ into secondary products (TBARS) in the frozen fillets. This delay in the lipid oxidation rate may increase the shelf life of frozen fillets.

Key words: lipid oxidation, transport, fish, TBARS, natural anesthetic.

\section{RESUMO}

O objetivo do trabalho foi avaliar se o uso do óleo essencial de Aloysia triphylla (OEAT) na água de transporte de peixes, in vivo como sedativo, poderia aumentar a estabilidade oxidativa de filés de jundiá (Rhamdia quelen) durante o armazenamento congelado. Avaliou-se a composição química do OEAT e dos filés dos peixes expostos ao OEAT (0, 30 ou $40 \mu \mathrm{L}$ $L^{-1}$ ), bem como o $\mathrm{pH}$ e indicadores de oxidação lipídica (dienos conjugados, DC; substâncias reativas ao ácido tiobarbitúrico,
TBARS) dos filés ao longo do armazenamento ( $-18 \pm 2^{\circ} \mathrm{C} / 17$ meses). $O \alpha$-e o $\beta$-citral foram os compostos majoritários do OEAT. $O$ tratamento com OEAT não modificou a composição centesimal dos filés de jundiá, mas $40 \mu L L^{-1}$ de OEAT reduziu o $\mathrm{pH}$ dos filés, comparado ao controle $(P<0,05)$. Foi observado maior teor inicial de DC nos filés dos tratamentos 30 e $40 \mu L L^{-1}$ de OEAT e menor valor de TBARS nos filés do tratamento $40 \mu \mathrm{L} \mathrm{L}^{-1}$ de OEAT após 6, 9 e 17 meses de congelamento, em comparação com os filés controle $(P<0,05)$. Os resultados indicam que o uso do OEAT como sedativo na água de transporte de jundiás retarda a degradação de produtos primários da oxidação lipídica (DC) em produtos secundários (TBARS) nos filés congelados. Este retardo na velocidade de oxidação lipídica pode ampliar a vida útil dos filés congelados.

Palavras-chave: oxidação lipídica, transporte, pescado, TBARS, anestésico natural.

\section{INTRODUCTION}

Silver catfish (Rhamdia quelen) is a freshwater fish found from southern Mexico to central Argentina, whose importance in aquaculture has grown, especially in Brazil (BARCELLOS et al., 2006), and which is well accepted by consumers (BARCELLOS et al., 2013). In commercial aquaculture, fish endure stress during capture, handling and transportation (PARODI et al., 2012). Besides putting the fish at risk of physical damage, meat quality may be also affected by stress. The increased muscle activity that is associated to stress causes an early onset of rigor mortis and accelerates lipid and protein oxidation during storage (ASHELY,

${ }^{\mathrm{I}}$ Colégio Politécnico, Universidade Federal de Santa Maria (UFSM), Santa Maria, RS, Brasil.

IINúcleo Integrado de Desenvolvimento em Análises Laboratoriais (NIDAL), Departamento de Tecnologia e Ciência dos Alimentos, Universidade Federal de Santa Maria (UFSM), 97105-900, Santa Maria, RS, Brasil. E-mail: tatiemanuelli@gmail.com. "Corresponding author.

IIIDepartamento de Fisiologia e Farmacologia, Universidade Federal de Santa Maria (UFSM), Santa Maria, RS, Brasil.

${ }^{\text {IV}}$ Departamento de Farmácia Industrial, Universidade Federal de Santa Maria (UFSM), Santa Maria, RS, Brasil. 
2007), which are critical in determining the quality and shelf life of fish (BOSWORTH et al., 2007).

One strategy to reduce pre-slaughter stress is the use of anesthetics (PARODI et al., 2012; ZEPPENFELD et al., 2013). However, the only anesthetic approved by the Food and Drug Administration for use in aquaculture, Tricaine Methanesulfonate (MS-222), cannot be applied within 21 days of slaughter if the fish is destined for human consumption in the U.S. or within 5 days in Canada (MEINERTZ et al., 2014). Accordingly, there has been increased interest in natural anesthetics and an eugenol-based product (AQUI-S ${ }^{\circledR} 20 \mathrm{E}$ ) was approved for sedating fish in New Zealand, Australia, Chile and Korea (ASHLEY, 2007). In Brazil, there are not yet laws to regulate the use of anesthetics for fish and the most commonly used anesthetic is benzocaine (FAÇANHA \& GOMES, 2005). The essential oil of Aloysia triphylla was recently patented as a sedative and anesthetic for aquatic animals (PI0904839-1A2).

A.triphylla(L'Herit)Britton(Verbenaceae) is an herb species that grows naturally in South America and has been used in popular medicine as an infusion to treat insomnia and anxiety and as an analgesic and sedative (CARNAT et al., 1999). A. triphylla leaves are used to give a lemon flavor to fish, chicken, vegetable and salad dishes, among others (FUNES et al., 2009). Anesthetic effects of its essential oil were attributed to its main components, $\alpha$-citral, $\beta$-citral and limonene (CARNAT et al., 1999; PARODI et al., 2012). In addition, in the in vitro DPPH (1,1-diphenyl-2-picrylhydrazyl) radical scavenging assay, the essential oil of $\boldsymbol{A}$. triphylla presented moderate antioxidant activity in comparison to the synthetic antioxidant butylhydroxyanisole (BHA), which is utilized commercially (ALI et al., 2011).

Among animal source foods, fish is more susceptible to deterioration because its $\mathrm{pH}$ is close to neutral and it contains a high content of nutrients that are easily utilized by micro-organisms (HOSSEINI et al., 2010). In addition, its high content of unsaturated fatty acids also leads to a reduced shelf life due to hydrolysis and especially lipid oxidation reactions, which results in undesirable alterations of color, flavor, odor and nutrient value (SAMPELS, 2013).

Lipid oxidation is a free radical chain reaction that comprises three main stages namely initiation (auto-oxidation), propagation and termination (SAMPELS, 2013). The conjugated dienes (CD) and hydroperoxides, which are formed during the initial stages, are considered primary products, while secondary products of lipid oxidation are formed during the termination stage.
These secondary products can be evaluated in fish by measuring thiobarbituric acid-reactive-substances (TBARS), which show the malondialdehyde (MDA) concentration (SAMPELS, 2013; VEECK et al., 2013; 2015). Natural antioxidants, such as the essential oils of plants may delay lipid oxidation due to the presence of terpenoid compounds, especially phenolic monoterpenes (VANDARÜNLÜ et al., 2003). The $\pi$ bonds are responsible for the chain-breaking antioxidant activity of terpenes (WOJTUNIK et al., 2005).

The aim of this research was to evaluate the use of essential oil of $\boldsymbol{A}$. triphylla (EOAT) in vivo, as a sedative in the water for transporting fish to increase the oxidative stability of silver catfish $(\boldsymbol{R}$. quelen) fillets during frozen storage.

\section{MATERIAL AND METHODS}

\section{A. triphylla (L' Her.) Britton Essential Oil (EOAT)}

The plant was collected in Frederico Westphalen (2722”S; $53^{\circ} 25^{\prime}$ 'W), Rio Grande do Sul, Brazil, identified by the botanist Dr. Gilberto Dolejal Zanetti (Dept. of Industrial Pharmacy, UFSM) and deposited in the herbarium at the Dept. of Biology, UFSM (SMDB No. 11169). A. triphylla was obtained from fresh leaves by hydrodistillation in a Clevenger during $3 \mathrm{~h}$ and stored in amber glass vials $\left(-20^{\circ} \mathrm{C}\right)$.

The composition of EOAT was evaluated in a Varian gas chromatographer (GC; Model CP - 3800) equipped with a Flame Ionizer Detector (FID) and a Saturno Mass Spectrometer (MS) with a $30 \mathrm{~m}$ x $0.25 \mathrm{~mm}$ $\mathrm{x} 0.25 \mu \mathrm{m}$ fused silica capillary column, VF-5 EM (Varian). The sample $(1 \mu \mathrm{L})$ was injected in split mode (1:20) for GC-MS and in splitless mode for GC-FID. The injector temperature was $250^{\circ} \mathrm{C}$, the carrier gas was He (1mL. $\left.\mathrm{min}^{-1}\right)$, and the column oven temperature was maintained at $50^{\circ} \mathrm{C}$ for $4 \mathrm{~min}$ and then heated to $280^{\circ} \mathrm{C}$ at $4^{\circ} \mathrm{C} \mathrm{m^{-1 }}$. The detector temperature was $310^{\circ} \mathrm{C}$. The GC-MS analysis was performed using electronionization $(70 \mathrm{eV})$. The AT components were identified by comparing the retention indices (RI) of the sample with those determined using a calibration curve of a homologous series of n-alkanes $\left(\mathrm{C}_{8}-\mathrm{C}_{32}\right)$ injected under the same chromatographic conditions as the samples and using fragmentation models of the mass spectra (ADAMS, 2007; NIST, 1998). Quantitative data were obtained from the peak areas in the GC-FID analysis.

Treatment of fish and freezing of fillets

Forty-five silver catfish ( $R$. quelen; $247.2 \pm 45.1 \mathrm{~g} ; 32.8 \pm 1.4 \mathrm{~cm}$ ) obtained from a fish farm (fed with commercial feed and raised in ponds) were 
placed in plastic bags at a load density of $260 \mathrm{~g} \mathrm{~L}^{-1}$ water ( 5 fish per bag), and transported on a paved road for $6 \mathrm{~h}$. Three independent replicates were performed for each of three treatments ( 3 bags by treatment, resulting in 15 fish by treatment) applied to the water used for transportation: control (water alone), 30 or $40 \mu \mathrm{L} \mathrm{L}^{-1}$ of EOAT (equivalent to 0,27 or $36 \mathrm{mg} \mathrm{L}^{-1}$, respectively, as the density of the essential oil is 0.90$)$. The EOAT was diluted in ethanol (1:10, $\mathrm{v} / \mathrm{v}$ ) and added to the transport water. Transport time, loading density and EOAT concentrations were chosen based on previous studies (GOLOMBIESKI et al., 2003; PARODI et al., 2012; PARODI et al., 2013). The amount of dissolved carbon dioxide, $\mathrm{pH}$, temperature, and total and unionized ammonia were verified in the water before and after transport and presented appropriate levels for the species (data published in DANIEL et al., 2014).

After transport, the fish were slaughtered by hypothermia, washed in potable water and cut into fillets by hand. One fillet from each repetition of each treatment was utilized immediately after slaughter to evaluate the chemical composition and lipid oxidation and the remaining fillets were stored at $-18 \pm 2^{\circ} \mathrm{C}$, in individual polystyrene trays covered by PVC film. Lipid stability of the fillets was evaluated by determining $\mathrm{CD}$ and TBARS levels throughout the 17-month period of frozen storage.

\section{Analysis of the fillets}

The proximate composition of the fillets was assessed immediately after slaughter by the AOAC method (1996), except for fat, which was evaluated according to BLIGH \& DYER (1959). Determination of $\mathrm{pH}$ was performed at a ratio of $1 \mathrm{~g}$ per $10 \mathrm{~mL}$ distilled water (PASTORIZA \& SAMPEDRO, 1994).

The CDs were determined in fat extracted by the method of BLIGH \& DYER (1959), where lipids were extracted and dissolved in $3 \mathrm{~mL}$ of cyclohexane and measured at 233nm (RECKNAGEL \& GLENDE, 1984). To determine TBARS, the fillet samples were homogenized with $1.5 \% \mathrm{KCl}(1: 5$, $\mathrm{m} / \mathrm{v}$ ) using an Ultra Turrax (IKA T18 Basic) and then centrifuged at $3.000 \times \mathrm{g}$ for $10 \mathrm{~min}$. The supernatant was incubated at $100^{\circ} \mathrm{C}$ for $15 \mathrm{~min}$ in a medium containing trichloroacetic acid and thiobarbituric acid. The reaction product was extracted with n-butanol and measured at 535nm (BUEGE \& AUST, 1978).

Statistical analysis

The Statistica 9.1 software was used to perform analyses. Data from the composition of the fillets were analyzed using one-way analysis of variance (ANOVA) and the remaining results were analyzed using two-way factorial ANOVA (3 treatments $\mathrm{x} 6$ time points). Differences between means were post hoc evaluated using Tukey's test. Differences were considered significant at $\mathrm{P}<0.05$.

\section{RESULTS AND DISCUSSION}

Forty-one compounds were identified in the EOAT, most of which were mono- and sesquiterpenoids. Compounds found in the highest concentrations were: (in g $100 \mathrm{~g}^{-1}$ oil) $29.4 \alpha$-citral; $20.8 \beta$-citral; 11.9 limonene; 5.6 caryophyllene, 3.3 cubenol, 3.0 geranyl acetate and 2.3 caryophyllene oxide; the remaining compounds were found in concentrations under $2 \mathrm{~g} 100 \mathrm{~g}^{-1}$. Results are in corroboration with other studies that found citral to be the main component of EOAT (ALI et al., 2011; PARODI et al., 2012). Generally, $\alpha$-citral is the main component, followed by $\beta$-citral and limonene (PARODI et al., 2012), all of which are considered to be safe food additives for human consumption by regulatory agencies in the U.S. (Code of Federal Regulation 21 CFR part 182.20; U.S. Food and Drug Administration) and Europe (Commission Implementing Regulation No. 872/2012; European Union).

Treatment with EOAT during transport did not modify the proximate composition of the fish fillets, which presented mean composition $(3.0 \pm 0.6 \%$ fat, $13.4 \pm 1.0 \%$ protein, $1.1 \pm 0.0 \%$ ash and $80.3 \pm 1.4 \%$ moisture), for all of the treatments $(n=9)$, similar to those reported by VEECK et al. (2013) for the species.

Throughout the storage period, the frozen fillets presented $\mathrm{pH}$ levels under 6.8 (Figure 1), which is the maximum allowed limit for fish destined for human consumption, according to Brazilian legislation (6.5 and 6.8 for internal and external fish muscles, respectively, BRASIL, 1997). There was an effect of storage time and treatment on $\mathrm{pH}$ levels $(\mathrm{P}<0.05)$, with no interaction between these variables. Levels of $\mathrm{pH}$ increased after 12 months frozen storage when compared to initial levels $(\mathrm{P}<0.05)$ for all treatments. Fillets from fish treated with $40 \mu \mathrm{L} \mathrm{L}^{-1}$ EOAT presented $\mathrm{pH}$ levels lower than those of the controls $(\mathrm{P}<0.05)$ throughout the storage period (Figure 1). The lower $\mathrm{pH}$ levels found for fillets from fish treated with EOAT may be the result of lower stress levels, which would lead to reduced glycogen use during transport. Following slaughter, muscle glycogen is degraded and releases glucose for energy production by the anaerobic glycolytic pathway, resulting in an accumulation of lactic acid and a reduction in $\mathrm{pH}$ (BAGNI et al., 2007). 


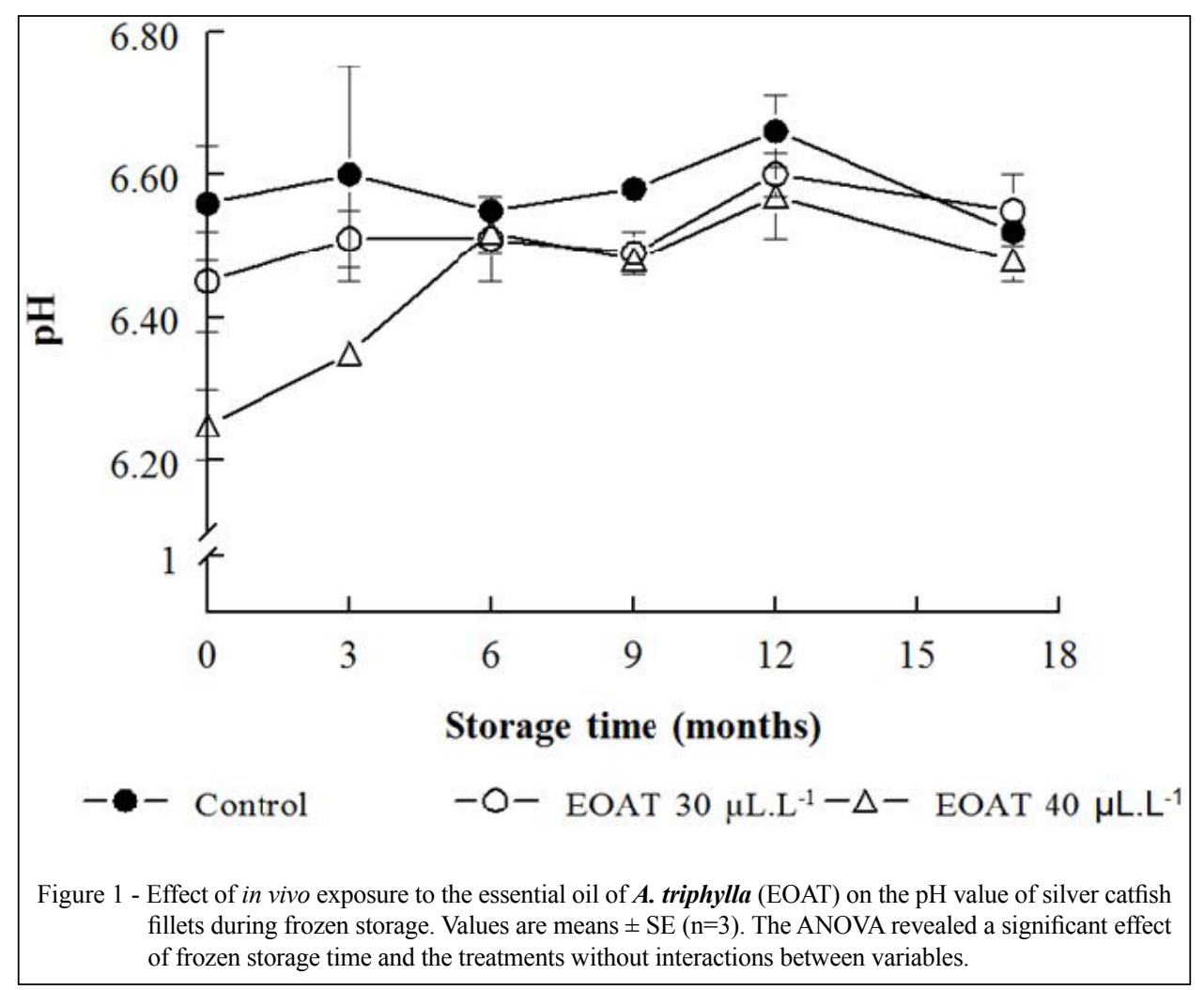

Therefore, the greater reserve of muscle glycogen at the time of slaughter resulted in greater accumulation of lactic acid and lower $\mathrm{pH}$ in the fish treated with EOAT. This hypothesis is in agreement with data of ZEPPENFELD et al. (2014), who reported higher lactate content in the muscle of silver catfish sedated with EOAT during transport in comparison to controls.

Lipid stability of the frozen fish fillets was assessed by measuring CD and TBARS levels (Figure 2). There was a time $\mathrm{x}$ treatment interaction $(\mathrm{P}<0.05)$ for $\mathrm{CD}$ levels (primary products of lipid oxidation) and for TBARS (secondary products of lipid oxidation). Fillets from fish treated with EOAT (30 and $40 \mu \mathrm{L} \mathrm{L}^{-1}$ ) had higher CD levels than those found in the controls at time point 0 (Figure 2A). However, fillets from fish treated with $40 \mu \mathrm{L} \mathrm{L}^{-1}$ EOAT had lower TBARS levels than those found in the controls after 6,9 and 17 months of frozen storage $(\mathrm{P}<0.05$; Figure $2 \mathrm{~B})$, which did not occur for the treatment with $30 \mu \mathrm{L} \mathrm{L}^{-1}$ of EOAT. These results indicated that exposure to $40 \mu \mathrm{L} \mathrm{L}^{-1}$ EOAT during transport led to an antioxidant effect on the frozen fillets, by delaying the degradation of primary lipid oxidation products $(\mathrm{CD})$ into secondary products (TBARS). Similar results were found in fillets sprinkled with Lippia alba extracts and in fillets from fish exposed in vivo to the essential oil of $\boldsymbol{L}$. alba, which showed delayed degradation of hydroperoxides into secondary oxidation products (TBARS), indicating an antioxidant activity (VEECK et al., 2013; 2015). In fact, some antioxidants (e.g., tocopherols) can increase primary lipid oxidation products by donating hydrogen to a peroxyl radical to form a lipid hydroperoxide while simultaneously decreasing the formation of low molecular weight volatile secondary oxidation products (DECKER et al., 2005). The reduction in the lipid oxidation rate caused by EOAT, especially with regard to the lower TBARS levels, may be important to increase the shelf life of frozen fish fillets, since the aldehydes resulting from lipid oxidation (assessed by TBARS levels) are responsible for a rancid odor and consequent rejection of oxidized food (DAMODARAN et al., 2008).

The proposed maximum acceptable limit for MDA levels were 1-2mg kg-1 (GILL, 1990). The fish fillets from control group and those treated with $30 \mu \mathrm{L} \mathrm{L}^{-1}$ EOAT reached this limit at the sixth month of frozen storage, while the fillets from fish treated with $40 \mu \mathrm{L} \mathrm{L}^{-1}$ EOAT did not reach this limit even after 17 months of storage (Figure $2 \mathrm{~B}$ ).

The delay in lipid oxidation of fillets from fish sedated with EOAT during transport may be 

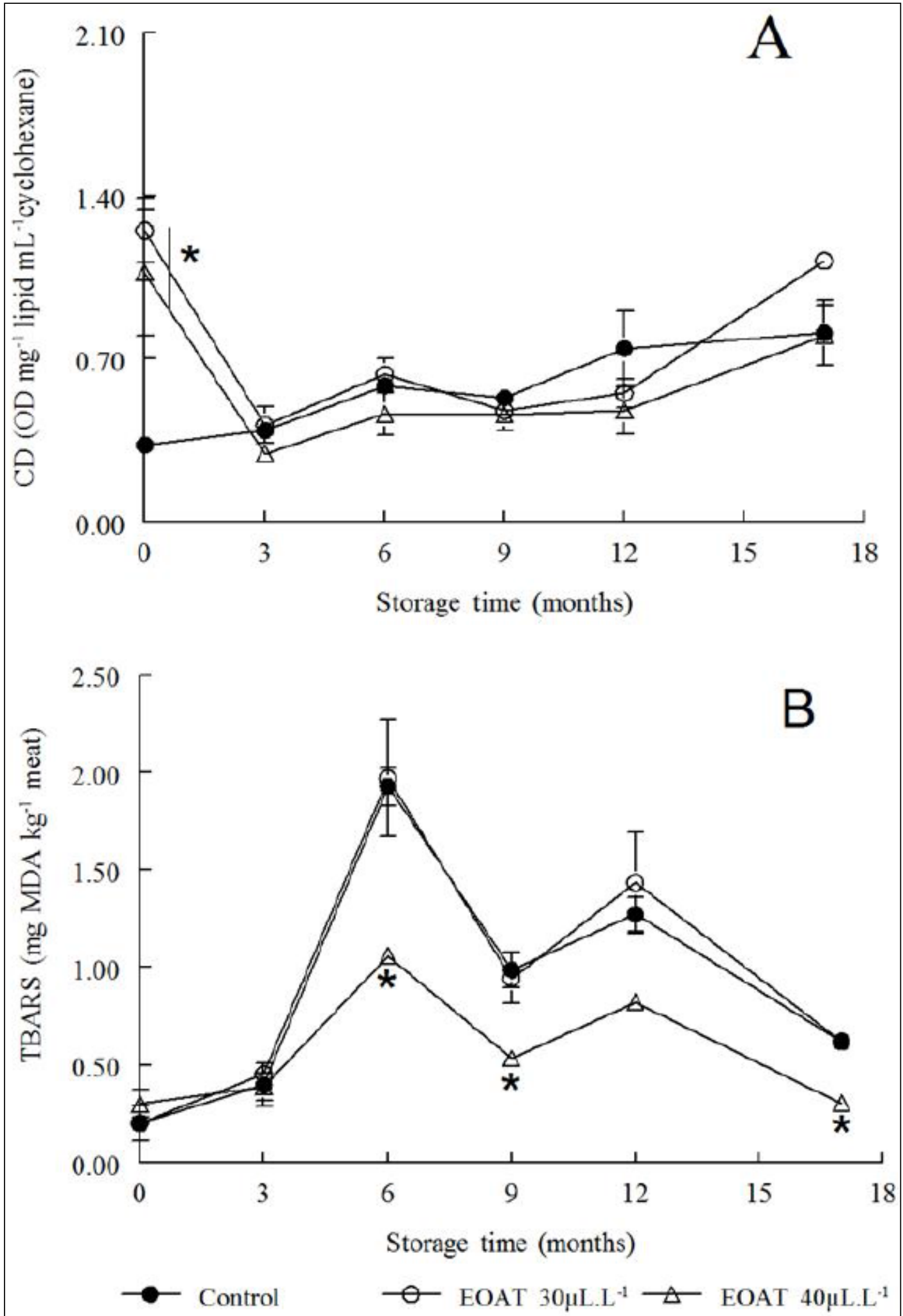

Figure 2 - Effect of exposure in vivo to the essential oil of $\boldsymbol{A}$. triphylla (EOAT) on the conjugated diene values (DC) (A) and thiobarbituric acid reactive substances (TBARS) (B) of silver catfish fillets during frozen storage. Values are means $\pm \mathrm{SE}(\mathrm{n}=3)$. OD: optical density. The ANOVA revealed a significant interaction time $\mathrm{x}$ treatment in DC and TBARS values. "Significantly different from control at the same time of frozen storage $(\mathrm{P}<0.05)$. 
related to the antioxidant capacity and inhibition of lipid peroxidation shown by EOAT when used as an anesthetic in vivo in silver catfish (GRESSLER et al., 2012). Exposure in vivo to EOAT immediately before slaughter reduced stress in the catfish by suppressing cortisol release and increasing the activity of antioxidant enzymes, catalase and glutathione S-transferase (GRESSLER et al., 2012). In addition, the antioxidant effect of EOAT may also be related to the removal of free radicals by antioxidant compounds present in the oil, since, in vitro, the oil presented moderate capacity to remove the DPPH radical when compared to BHA (ALI et al., 2011). Despite presenting a promising antioxidant effect on the frozen fillets and even though EOAT is a natural compound extracted from a plant that is widely used in tea and for spice in the human diet, it is still necessary to evaluate its toxicological safety before it can be used in foods.

\section{CONCLUSION}

The use of $\boldsymbol{A}$. triphylla essential oil $\left(40 \mu \mathrm{LL}^{-1}\right)$ in fish transport water reduced muscle $\mathrm{pH}$ after slaughter and delayed lipid oxidation of frozen silver catfish fillets, especially the degradation of primary products of lipid oxidation (CD) into secondary products (TBARS). The use of EOAT as a sedative in fish transport water contributes to extend the shelf life of frozen fillets.

\section{BIOETHICS AND BIOSSECURITY COMMITTEE APPROVAL}

This study was approved by the Ethics Committee on Animal Use (092/2011).

\section{ACKNOWLEDGEMENTS}

Supported by PRONEX (Fundação de Amparo à Pesquisa do Estado do Rio Grande do Sul (FAPERGS)/Conselho Nacional de Desenvolvimento Científico e Tecnológio (CNPq)), CT-AGRO (MCT/MPA/FINEP), and Casadinho/PROCAD (MCT/ CNPq/MEC/CAPES). T.E. and B.B. are Research Fellowships from CNPq. L.F.F. and B.K. received Scientific Initiation Fellowships from PIBIC-CNPq/UFSM.

\section{REFERENCES}

ADAMS, R.P. Identification of essential oil components by gas chromatography/quadrupole mass spectroscopy. 4.ed. Illinois: Allured Publishing, 2007. 804p.

ALI, H.F.M. et al. Evaluation of antioxidant and antimicrobial activity of Aloysia triphylla. Electronic Journal of Environmental, Agricultural and Food Chemistry, v.10, n.8, p.2689-2699, 2011.

AOAC (ASSOCIATION OF OFFICIAL ANALYTICAL CHEMISTS). Official Methods of Analysis of the Association of Official Analytical Chemists. 16.ed. Arlington, Virginia, 1996. V.16, 1137p.

ASHELY, P.J. Fish welfare: current issues in aquaculture. Applied Animal Behaviour Science, v.104, p.199-235, 2007. Available from: <http://dx.doi.org/10.1016/j.applanim.2006.09.001>. Accessed: Feb. 17, 2015.

BAGNI, M. et al. Pre-slaughter crowding stress and killing procedures affecting quality and welfare in sea bass (Dicentrarchus labrax) and sea bream (Sparus aurata). Aquaculture, v.263, p.52-60, 2007. Available from: <http://dx.doi.org/10.1016/j. aquaculture.2006.07.049>. Accessed: Feb. 17, 2015.

BARCELLOS, L. J. G. et al. Previous chronic stress does not alter the cortisol response to an additional acute stressor in jundiá (Rhamdia quelen, Quoy and Gaimard) fingerlings. Aquaculture, v.253, p.317-321, 2006. Available from: $<\mathrm{http}$ ://dx.doi.org/10.1016/j.aquaculture.2005.05.035>. Accessed: Feb. 17, 2015.

BARCELLOS, L.J.G. et al. Workshop sobre jundiá: história e perspectiva. Passo Fundo: UPF, 2013. 266p.

BOSWORTH, B.G. et al. Effects of rested-harvest using the anesthetic AQUI-S (TM) on channel catfish, Ictalurus punctatus, physiology and fillet quality. Aquaculture, v.262, p.302-318, 2007. Available from: <http://dx.doi.org/10.1016/j. aquaculture.2006.10.035>. Accessed: May 17, 2015.

BRASIL. Ministério da Agricultura Pecuária e Abastecimento. Decreto-Lei n. 30.691 de 29 de Março de 1952, alterado pelo decreto n. 1.255 de 25 de Junho de 1962, n. 1.236 de 02 de setembro de 1994, n. 1.812 de 08 de fevereiro de 1996 e n. 2.244 de 04 de junho de 1997. Aprova o novo Regulamento da Inspeção Industrial e Sanitária de Produtos de Origem Anila - R.I.I.S.P.O.A. Departamento Nacional de Inspeção de Produtos de Origem Animal. Diário Oficial [da] República Federativa do Brasil, Brasília, DF, 1997.

BLIGH, E.G.; DYER, W.J. A rapid method of total lipid extraction and purification. Canadian Journal of Biochemistry Physiology, v.37, n.8, p.911-917, 1959. Available from: <http://dx.doi. org/10.1139/o59-099>. Accessed: Feb. 17, 2015.

BUEGE, J.A.; AUST, S.D. Microsomal lipid peroxidation. Methods in Enzymology, v.52, p.302-310, 1978. Available from: <http://dx.doi. org/10.1016/S0076-6879(78)52032-6>. Accessed: Feb. 17, 2015.

CARNAT, A. et al. The aromatic and polyphenolic composition of lemon verbena tea. Fitoterapia, v.70, n.1, p.44-49, 1999. Available from: <http://dx.doi.org/10.1016/S0367326X(98)00016-1>. Accessed: Jun. 10, 2014.

DAMODARAN, S. et al. Fennema's food chemistry. 4.ed. Boca Raton: CRC, 2008. 1144p

DANIEL, A.P. et al. Using the essential oil of Aloysia triphylla (L'Her.) Britton to sedate silver catfish (Rhamdia quelen) during transport improves the chemical and sensory qualities of the fish during storage in ice. Journal of Food Science, v.79, n.6, p.12051211, 2014. Available from: <http://dx.doi.org/10.1111/17503841.12463>. Accessed: Feb. 17, 2015.

DECKER, E.A. et al. Measuring antioxidant effectiveness in food. Journal of Agricultural and Food Chemistry, v.53, p.4303-4310, 
2005. Available from: <http://dx.doi.org/10.1021/jf058012x>. Accessed: Jun. 24, 2015.

FAÇANHA, M.F.; GOMES, L.C. Efficacy of menthol as an anesthetic for tambaqui (Colossoma macropomum, Characiformes: Characidae). Acta Amazonica, v.35, p.71-75, 2005.

FUNES, L. et al. Correlation between plasma antioxidant capacity and verbascoside levels in rats after oral administration of lemon verbena extract. Food Chemistry, v.117, p.589598, 2009. Available from: <http://dx.doi.org/10.1016/j. foodchem.2009.04.059>. Accessed: Feb. 17, 2015.

GILL, T.A. Objective analysis of seafood quality. Food Reviews International, v.6, p.681-714, 1990.

GOLOMBIESKI, J.I. et al. Transport of silver catfish (Rhamdia quelen) fingerlings at different times, load densities, and temperatures. Aquaculture, v.216, p.95-102, 2003. Available from: $<\mathrm{http} / / / \mathrm{dx}$.doi. org/10.1016/S0044-8486(02)00256-9>. Accessed: Feb. 17, 2015.

GRESSLER, L.T. et al. Silver catfish Rhamdia quelen immersion anaesthesia with essential oil of Aloysia triphylla (L'Herit) Britton or tricaine methanesulfonate: effect on stress response and antioxidant status. Aquaculture Research, v.45, p.1061-1072, 2012. Available from: <http://dx.doi.org/10.1111/are.12043>. Accessed: May 15, 2014.

HOSSEINI, S.V. et al. Influence of the in vivo addition of alphatocopheryl acetate with three lipid sources on the lipid oxidation and fatty acid composition of Beluga sturgeon, Huso huso, during frozen storage. Food Chemistry, v.118, p.341-348, 2010. Available from: <http://dx.doi.org/10.1016/j.foodchem.2009.04.131>. Accessed: May 15, 2014.

MEINERTZ, J.R. et al. Depletion of eugenol residues from the skinon fillet tissue of rainbow trout exposed to 14C-labeled eugenol. Aquaculture, v.430, p.74-78, 2014. Available from: $<$ http://dx.doi. org/10.1016/j.aquaculture.2014.03.050>. Accessed: Jun. 27, 2014.

NIST (NATIONAL INSTITUTE OF STANDARDS AND TECHNOLOGY). NIST Scientific and Technical Databases. The NIST Mass Spectral Search Program for the NIST/EPA/NIM Mass Spectral Library, Version 1.7, 1998. 1 CD.

PARODI, T.V. et al. The anesthetic efficacy of eugenol and the essential oils of Lippia alba and Aloysia triphylla in postlarvae and sub-adults of Litopenaeus vannamei (Crustacea, Penaeidae). Comparative Biochemistry and Physiology Part C: Pharmacology, Toxicology and Endocrinology, v.155, p.462-468, 2012. Available from: <http://dx.doi.org/10.1016/j. cbpc.2011.12.003>. Accessed: Feb. 17, 2015.
PARODI, T.V. et al. Anesthetic activity of the essential oil of Aloysia triphylla and effectiveness in reducing stress during transport of albino and gray strains of silver catfish, Rhamdia quelen. Fish Physiology Biochemistry, v. 40, n.2, p. 323-334, 2013a. Available from: <http://dx.doi.org/10.1007/s10695-0139845-z>. Accessed: Feb. 17, 2015.

PASTORIZA, L.; SAMPEDRO, G. Influence of ice storage on Ray (Raja clavata) wing muscle. Journal of Science of Food and Agriculture, v.64, p.9-18, 1994. Available from: <http://dx.doi. org/10.1002/jsfa.2740640103>. Accessed: Feb. 17, 2015.

RECKNAGEL, R.O.; GLENDE, E.A.J. Spectrophotometric detection of lipid conjugated dienes. Methods in Enzymology, v.105, p.331-337, 1984. Available from: <http://dx.doi. org/10.1016/S0076-6879(84)05043-6>. Accessed: Feb. 17, 2015.

SAMPLES, S. Oxidation and antioxidants in fish and meat from farm to fork. Rijeka (Croatia): Food Industry, INTECH, 2013. Chapter 6. Available from: <http://dx.doi.org/10.5772/53169>. Accessed: Feb. 17, 2015.

VARDAR-ÜNLÜ, G. et al. Antimicrobial and antioxidant activity of essential oil and metanol extract of Tymus pectinatus Fisch. et Mey. var. pectinatus (Lamiaceae). Journal of Agricultural and Food Chemistry, v.51, p.63-67, 2003. Available from: <http:// dx.doi.org/10.1021/jf025753e>. Accessed: Jun. 23, 2015.

VEECK, A.P.L. et al. Lipid stability during the frozen storage of fillets from silver catfish exposed in vivo to the essential oil of Lippia alba (Mill.) N.E. Brown. Journal of the Science of Food and Agriculture, v.93, p.955-960, 2013. Available from: <http:// dx.doi.org/10.1002/jsfa.5833>. Accessed: Feb. 17, 2015.

VEECK, A.P.L. et al. Lipid stability of frozen common carp fillets treated with Lippia alba extract. Ciência Rural, v.45, p.11131119, 2015. Available from: <http://dx.doi.org/10.1590/01038478cr20140785>. Accessed: Jun. 23, 2015.

WOJTUNIK, K.A. et al. Model studies on the anioxidant activity of common terpenoid constituents of essential oils by means of the 2,2-diphenyl-1-picrylhydrazyl method. Journal of Agricultural and Food Chemistry, v.62, p.9088-9094, 2014. Available from: $<$ http://dx.doi.org/10.1021/jf502857s >. Accessed: Jun. 23, 2015.

ZEPPENFELD, C.C. et al. Physiological and biochemical responses of silver catfish, Rhamdia quelen, after transport in water with essential oil of Aloysia triphylla (L'Herit) Britton. Aquaculture, v.418-419, p.101-107, 2014. Available from: $\quad<$ http://dx.doi.org/10.1016/j.aquaculture.2013.10.013>. Accessed: Feb. 17, 2015. 